\title{
The Characterization and Activity of Protease Enzyme on Different Days of Tadpoles [Pelophylax ridibundus (Pallas, 1771)]
}

\author{
Hülya Şereflişan ${ }^{1}$ (D), Ahmet Alkaya ${ }^{1}$ (D), Kaya Gökçek² (D)
}

Cite this article as: Sereflisan, H., Alkaya, A., Gokcek, K. (2019). The characterization and activity of protease enzyme on different days of tadpoles [Pelophylax ridibundus (Pallas, 1771)]. Aquatic Sciences and Engineering, 34(4), 112-115.

ORCID IDs of the authors: H.Ş. 0000-0002-2510-3714; A.A. $0000-0003-2117-7799$;

K.G. 0000-0002-7837-8009;

'Iskenderun Technical University, Marine Sciences and Technology Faculty, Hatay, Turkey ${ }^{2}$ Mustafa Kemal University, Agriculture Faculty Animal Sciences Department, Hatay, Turkey

Submitted:

18.05.2019

Accepted:

10.09.2019

Online published:

27.09.2019

Correspondence:

Ahmet Alkaya

E-mail:

ahmtalkaya674@gmail.com

(C) Copyright 2019 by Aquatic Sciences and Engineering Available online at

https://dergipark.org.tr/ase

\begin{abstract}
In this study, protease enzyme activity of Pelophylax ridibundus (Pallas, 1771) tadpoles was determined during the larval period starting from 25 Gosner stage (1960). When the P. ridibundus tadpoles reached the 25 Gosner stage (1960) on the $22^{\text {nd }}$ day, the sampling was continued until the metamorphosis was completed by sampling at 5-day intervals. Initial average weight and length of the tadpoles were $0.076 \mathrm{~g}$ and $6.42 \mathrm{~mm}$, respectively. The tadpoles were fed with pellet feed the size of $2 \mathrm{~mm}$ and $39 \%$ crude protein content twice a day in the morning and afternoon. The differences in the protease activity between the $22^{\text {nd }}$ day and the $62^{\text {nd }}$ day of the metamorphosis were found statistically significant $(P<0.05)$. It has been observed that the protease enzyme reached maximum level at the $32^{\text {nd }}$ day. In the next stages, protease activity showed a tendency to increase and decrease up to metamorphosis. These results can be used as the basis for the most appropriate nutritional formulation for $P$. ridibundus in the larval stage.
\end{abstract}

Keywords: Pelophylax ridibundus, frog, acid protease, larval period, metamorphosis

\section{INTRODUCTION}

Most adult amphibians are fed on insects, while a small part are carnivores because they eat live invertebrates. The anuran tadpoles are herbivorous and their diets may also include plant material as well as aquatic invertebrates. The functional development of digestive organs is very important in the digestibility of the tadpole. In particular, in the frog culture where artificial feeds with high protein values are preferred in their diet, the digestive enzyme system mainly contains protease, amylase and lipase (Klahan and Yuangsoi, 2012). In the larval period, which is the most important step in the feeding of frogs, there is little information about how these animals are fed. According to the needs of the larvae, the deficiency in feeding resulted in death with the emergence of larval diseases (Veiga et al., 1998; Seixas Filho et al., 1998). In other zoological groups, the rela- tionship between the nutrition regime and the digestive system has been studied extensively and satisfactory results have been obtained by formulating the feed used to be manipulated (Seixas Filho et al., 2000). However, tadpole nutrition is far from establishing requirement standards that can be used by nutritionists. It is necessary to know the digestive physiology of these animals in order to identify the feed formulation in accordance with the nutritional requirements of the larvae at different stages of development. Furthermore, the effective use of the feed is directly related to the digestion process which is the basis of enzymes. In particular, the diets currently used in frog breeding have $40 \%$ crude protein content, but they contain the basic ingredients necessary for fish, but the needs for the tadpole frog is insufficient. In addition, nutritional habits and nutritional requirements of frogs vary at each stage of their development. Due to the structural changes that oc- 
cur during the development of larvae, nutrients need to be higher and nutritional deficiencies should be avoided (Barbosa et al., 2005; Oliveira-Bahia, 2007).

Generally, the use of feeds with high crude protein values in frog cultivation has led to good performance both in the larval period (Carmona-Osalde et al., 1996; Albinati et al., 2000; Albinati et al., 2001; Hayashi et al., 2004) and in other developmental periods (Barbalho, 1991; Braga and Lima, 2001). In addition, 26.6\% to $33.6 \%$ of crude protein levels were reported to be suitable for larval development (Barbosa et al., 2005), but the use of feeds with protein values of $22.5 \%$ may cause high mortality. For this reason, it is important to understand the relationship between the enzymes involved in digestion and the percentages of carbohydrates, proteins, and fats in the diet to increase meat production in frogs.

Studies report that adult amphibians fed with different diets do not exhibit any changes in the activity of intestinal enzymes, but alter the digestive performance of different diets used in feeding the tadpole (Toloza and Diamond, 1990; Sabat and Bozinovic, 1996). In addition, studies on the enzyme activity profiles of animals eating controlled diets are needed.

Although there are studies on the study of the enzymatic activity in amphibians (Etkin, 1968; Leone et al., 1976; Braga et al., 2004; Braga et al., 2006; Oliveira-Bahia, 2007), studies on the relationship between nutrition levels and growth in the literature have been reported to be inadequate (Barbosa et al., 2005). In some studies, the effects of some variables on larval growth, such as the period of light (Bambozzi et al., 2004), stock density (Hayashi et al., 2004) and protein levels (Carmona-Osalde et al., 1996) were investigated.

Metamorphosis, period of major post-embryonic transformations that involving morphological, physiological, biochemical, and behavioral changes. Also, changes the lifestyle of frog larvae. Metamorphosis in amphibians is the development of structures and functions that are important in the transformation of larval structures into beneficial structures in adults (Duellman and Trueb, 1986).

Morphological changes are observable changes, such as the formation of the lung, the development of the dermal glands of the eyelids, the formation of the mouth and tongue, and the differentiation of the digestive system (Bonneville, 1963; Bonneville and Weinstock 1970; Thibaudeau and Altig, 1988; Paulson and Robinson 1995; Rovira et al., 1993). Proteolytic enzymes play an important role in performing these morphological and physiological changes before and during metamorphosis. Proteolitic enzymes are used as energy reserves in metamorphosis as a result of feeding of living organisms. In addition, the feeding strategies formed by knowing the physiological events occurring in the larval period and the changes due to the days in the activities of these enzymes will accelerate the larval development and increase the survival rate.

The aim of this study was to determine the protease enzyme activity of Pelophylax ridibundus (Pallas, 1771) tadpoles fed with a protein ratio of $39 \%$ starting from 25 Gosner stage (1960) during the larval period. The results of the study will light on obtaining the most suitable feed ration for $P$. ridibundus, which is an economically important species.

\section{MATERIAL AND METHODS}

This study was carried out to determine protease enzyme activity on $P$. ridibundus tadpoles grown in the frog production facility of Aydıncık in Mersin, Turkey. Larval tadpole sampling was performed on the $22^{\text {nd }}$ day with the Gosner 25 (1960) level at 5-day intervals and this process was continued until the metamorphosis was completed. In this study, $6 \mathrm{~m}^{2}$ ponds were used in the cultivation of tadpole larvae. The water of the ponds was changed $50 \%$ once a day and the temperature of the ponds was measured as $23.0 \pm 1.0^{\circ} \mathrm{C}$ during the study period. Initial average weight and length of the tadpoles were $0.076 \mathrm{~g}$ and $6.42 \mathrm{~mm}$, respectively. The tadpoles were fed with pellet feed the size of $2 \mathrm{~mm}$ and $39 \%$ crude protein content twice a day in the morning and afternoon (Table 1).

\begin{tabular}{lc}
\hline Table 1. & $\begin{array}{l}\text { Chemical analysis of formulated pellet food for } \\
\text { P. ridibundus tadpoles }\end{array}$ \\
\hline Content & Percent (\%) \\
\hline Moisture & 4.54 \\
Crude Protein & 39 \\
Fat & 22.88 \\
Ash & 14.74 \\
\hline
\end{tabular}

Basic composition: fish meal, chicken meal and fish oil.

Pellet food content analyzes used in the feeding study were conducted in Iskenderun Technical University Marine Sciences and Technology Faculty Aquaculture Laboratory. The tadpole samples for analysis were stored in the Hettich freezer at $-80^{\circ} \mathrm{C}$.

\section{Determination of protease activities}

Total protease activities of $P$. ridibundus tadpoles was measured as described by Walter (1984), using casein $\left(10 \mathrm{mg} \mathrm{ml}^{-1}\right)$ in $50 \mathrm{mM}$ Tris- $\mathrm{HCl}$ buffer at $\mathrm{pH} 9$ as the substrate. The mixtures including extracts of tadpoles were incubated with the substrate and then the reaction was stopped by addition of $500 \mu$ l trichloroacetic acid (TCA) (120 $\left.\mathrm{g} \mathrm{L}^{-1}\right)$. The absorbance was recorded at $280 \mathrm{~nm}$. All measurements were carried out in triplicate. The soluble protein concentrations of $P$. ridibundus tadpole were determined according to Brasford (1976).

\section{Statistical methods}

Data was analyzed by using SPSS 17.0 statistics software. Comparisons were made using a one-way ANOVA test. Then, a PostHoc Tukey multiple-comparison test was used for significant differences at the $\mathrm{P}<0.05$ level.

\section{RESULTS AND DISCUSSION}

The results of the analysis of protease enzyme activities with $P$. ridibundus tadpoles are given in Table 2. The differences between the $22^{\text {nd }}$ day of protease activity larvae and the $62^{\text {nd }}$ day of the metamorphosis were found statistically significant $(P<0.05)$. It has 
Table 2. The changes observed in protease activities (mean \pm standard error (SE))

\begin{tabular}{ll}
\hline Day & Protease Activities $(\mathrm{U} / \mathrm{ml})$ \\
\hline 22 & $830.50 \pm 64.19^{\mathrm{bc}}$ \\
27 & $950.31 \pm 62.31^{\mathrm{c}}$ \\
32 & $1600.22 \pm 12.61^{\mathrm{d}}$ \\
37 & $675.76 \pm 13.94^{\mathrm{b}}$ \\
42 & $977.17 \pm 14.79^{\mathrm{c}}$ \\
47 & $392.08 \pm 25.08^{\mathrm{a}}$ \\
52 & $659.93 \pm 40.72^{\mathrm{b}}$ \\
57 & $739.36 \pm 32.86^{\mathrm{b}}$ \\
62 & $451.24 \pm 17.38^{\mathrm{a}}$ \\
\hline In all lines, means with different superscripts are significantly different from \\
each other $(\mathrm{P}<0.05)$
\end{tabular}

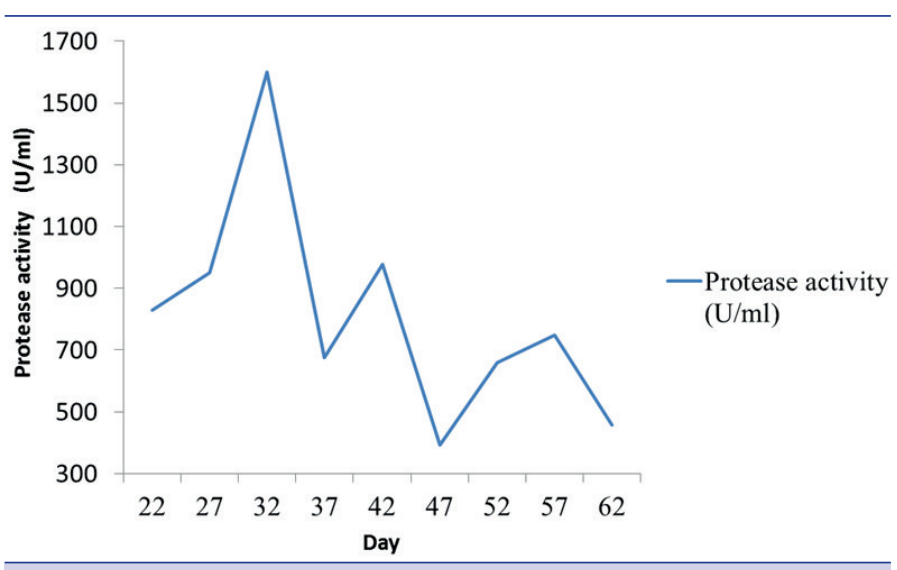

Figure 1. Protease activity on different days.

been observed that the protease enzyme reached maximum level at the $32^{\text {nd }}$ day, increasing from the 25 Gosner stage (1960) (day 22). After that, the increases and decreases in protease enzyme activity were detected until metamorphosis (Figure 1).

Santos et al. (2016) with study Lithobates catesbeianus showed that the increase in the amount of digestive enzymes before metamorphosis is important to increase the amount of metamorphosis thanks to the increase in the energy needed for the growth of the living organism detected. In our study with $P$. ridibundus tadpoles, the highest protease activity was found on day 32 $(1600.22 \pm 12.61 \mathrm{U} / \mathrm{ml})$ since the beginning of nutrition that this increase continued until the metamorphosis and the digestive system were completed. With the growth slowed after 30 days, the amount of energy required for development will decrease and the enzyme activity will be physiologically limited by the tadpoles (Seixas Filho et al., 2010). During the study period 32-37. $(675.76 \pm 13.94 \mathrm{U} / \mathrm{ml}), 42-47$. (392.08 $\pm 25.08 \mathrm{U} / \mathrm{ml})$ and 57-62. $(451.24 \pm 17.38 \mathrm{U} / \mathrm{ml})$ days, the amount of protease was decreased.

Seixas Filho et al. (2010) reported that the tadpoles of Rana catesbeiana were fed with $28 \%$ crude protein, the amylase enzyme was more active between 30 and 45 days and the tadpoles were fed with mostly content of carbohydrate diets. In our study, a decrease in protease activity was observed in $32 \mathrm{nd}-37^{\text {th }}$ days, although there was an increase again in protease activity from the $37^{\text {th }}$ day (Figure 1). P. ridibundus tadpoles reached the metamorphosis stage on the $42^{\text {nd }}$ day and the process ended on the $62^{\text {nd }}$ day. As a result of our study, the amount of protease obtained from Oliveira-Bahia (2007) was similar to the results of the study.

The use of feeds with high crude protein values in frog culture has led to good performance in both larval stages (Carmona-Osalde et al., 1996; Albinati et al., 2000, 2001; Hayashi et al., 2004) and other developmental periods (Barbalho, 1991; Braga \& Lima, 2001). In our study, tadpoles of $P$. ridibundus were fed with a pellet food containing $39 \%$ crude protein. Seixas Filho et al. (2010) reported that bullfrog tadpoles fed commercial frog feed with $28 \%$ crude protein content obtained good results in terms of enzyme activity.

Klahan and Yuangsoi (2012) reported that Rana rugulosa in 45day tadpoles were more prone to protease activity than those with 60-day tadpoles. In our study, the 42-day $P$. ridibundus tadpoles $(977.17 \pm 14.79 \mathrm{U} / \mathrm{ml})$ were found to have more protease than the 62-day $(451.24 \pm 17.38 \mathrm{U} / \mathrm{ml})$ individuals. In this study, it was determined that the protease amount of $P$. ridibundus tadpoles $(451.24 \pm 17.38 \mathrm{U} / \mathrm{ml})$ decreased in the last period of the metamorphosis phase (62 ${ }^{\text {nd }}$ day). The reason for this decrease in the amount of protease is due to the maintenance of a number of morphological changes such as the consumption of metabolic energy in the loss of the tail and the tadpoles consuming a smaller amount of food in the last stages of metamorphosis than in previous periods (Gonçalves et al., 2015).

\section{CONCLUSION}

As a result, $P$. ridibundus tadpoles fed with $39 \%$ crude protein were found to have more protease activity at the beginning of the larval development period than in other periods. In our study, it was emphasized that appropriate dietary formulations should be formed so that it can be consumed effectively by frogs on different days of the larval period.

Ethics Committee Approval: This study was carried out accordance with animal welfare and the ethics of trial.

Conflict of Interest: Author has no conflict of interest to report.

\section{REFERENCES}

Albinati, R. C. B., Lima, S. L., Tafuri, M. L., \& Donzele, J. L. (2000). Digestibilidade aparente de dois alimentos protéicos e três energéticos para girinos de rã-touro (Rana catesbeiana Shaw, 1802). Revista Brasileira de Zootecnia, 29(6), 2151-2156. http://www.sbz.org. br/revista/artigos/2715.pdf

Albinati, R. C. B., Lima, S. L., \& Donzele, J. L. (2001). Níveis de energia digestível na ração de girinos de rã-touro. Revista Brasileira de Saúde da Produção Animal, 2(2), 48-52. http://www.repositorio.ufba. $\mathrm{br} / \mathrm{ri} / \mathrm{handle} / \mathrm{ri} / 1840$

Bambozzi, A. C., Seixas-Filho, J. D., Thomaz, L. A., Oshiro, L. M. Y., Braga, L. G. T., \& Lima, S. L. (2004). Efeito do fotoperíodo sobre o desenvolvimento de girinos de rã-touro (Rana catesbeiana Shaw, 1802). Revista Brasileira de Zootecnia, 1(1), 1-7. [CrossRef] 
Barbosa, J. M., Silveira, A. M., \& Gomide, C. A. (2005). Crescimento heterogêneo de girinos de rã-touro alimentados com diferentes rações. Pesquisa Agropecuária Brasileira, 40(10), 1015-1019. [CrossRef]

Bonneville, M. A. (1963). Fine structural changes in the intestinal epithelium of the bullfrog during metamorphosis. The Journal of cell biology, 18(3), 579-597. [CrossRef]

Bonneville, M. A., \& Weinstock, M. (1970). Brush border development in the intestinal absorptive cells of Xenopus during metamorphosis. The Journal of cell biology, 44(1), 151-171. [CrossRef]

Braga, L. G. T., \& Lima, S. L. (2001). Influência da temperatura ambiente no desempenho da rã-touro, Rana catesbeiana (Shaw, 1802) na fase de recria. Revista Brasileira de Zootecnia, 30(6), 1659-1663. [CrossRef]

Braga, L. G. T., Oliveira, M. D. A., Lima, W. C., \& Euclydes, R. F. (2004). Atividade da tripsina em rã-touro na fase pós-metamórfica. Revista Brasileira de Zootecnia, 33(4), 821-827. [CrossRef]

Braga, L. G. T., Oliveira, M. G. A., Lima, W. C., \& Euclydes, R. F. (2006). F. Atividade enzimática da lipase em rã-touro na fase pós-metamórfica. Scientia Agrícola, 63(5), 821-827. [CrossRef]

Brasford, M. M. (1976). A rapid and sensitive method for quantitation of microgram quantities of protein utilizing the principle of protein-dye binding. Anal. Biochem., 72, 248-254. [CrossRef]

Carmona-Osalde, C., Olvera-Novoa, M. A., Rodriguez-Serna, M., \& Flores-Nava, A. (1996). Estimation of the protein requirement for bullfrog (Rana catesbeiana) tadpoles, and its effect on metamorphosis ratio. Aquaculture, 141(3-4), 223-231. [CrossRef]

Duellman, W. E., \& Trueb, L. (1986). Biology of Amphibians. New York, United States of America, McGraw-Hill Press., 613 pp.

Etkin, W. (1968). Hormonal control of amphibian metamorphosis. In Etkin, W. \& Gilbert, L. I. (Eds.) In Metamorphosis: A Problem in Developmental Biology (pp. 314-348). Appleton, New York, Academic Press., 500pp.

Gonçalves, A. M., Santos, L. F., Santana, C. C., Colosio, R. R., \& Pizauro, J. M. (2015). Activity of Tail Phosphatases: A Study during Growth and Metamorphosis of Lithobates catesbeianus. Copeia, 103(3), 634-638. [CrossRef]

Gosner, K. L. (1960). A simplified table for staging anuran embryos and larvae with notes on identification. Herpetologica, 16(3), 183-190.

Hayashi, C., Soares, C. M., Galdioli, E. M., Furuya, V. R. B., \& Boscolo, W. R. (2004). Desenvolvimento de girinos de rã-touro (Rana catesbeiana Shaw, 1802) cultivados em diferentes densidades de estocagem em tanques-rede. Revista Brasileira de Zootecnia, 33(1), 14-20. [CrossRef]

Klahan, R., \& Yuangsoi, B. (2012). The Characterization and Activity of Digestive Enzymes in Different Sizes of Common Lowland Frog (Rana rugulosa). International Journal of Environmental and Rural Development, 3(2), 114-120. http://iserd.net/ijerd61/IJERD\%206-110.pdf

Leone, F., Lambert-Gardini, S., Sartori, C., \& Scapin, S. (1976). Ultrastructural analysis of some functional aspects of Xenopus laevis pancreas during development and metamorphosis. Development, $36(3), 711-724$.
Oliveira-Bahia, V. R. L., (2007). Morfologia e enzimologia do sistema digestório dos girinos da rã-touro (Rana catesbeiana) durante o desenvolvimento e metamorfose (Master Thesis). Universidade Estadual Paulista, Jaboticabal, Brasil.

Paulson, P. E., \& Robinson, T. E. (1995). Amphetamine-Induced timedependent sensitization of dopamine neurotransmission in the dorsal and ventral striatum: A microdialysis study in behaving rats. Synapse, 19(1), 56-65. [CrossRef]

Rovira, J., Villaro, A. C., Bodegas, M. E., Valverde, E., \& Sesma, P. (1993). Structural study of the frog Rana temporaria larval stomach. Tissue and Cell, 25(5), 695-707. [CrossRef]

Sabat, Pablo., \& Bozinovic, F. (1996). Dietary chemistry and allometry of intestinal disaccharidases in the toad Bufo spinulosus. Rev Chil Hist Nat., 69, 387-391. http://rchn.biologiachile.cl/pdfs/1996/3/ Sabat_\%26_Bozinovic_1996.pdf

Santos, L. F. J. D., de Oliveira-Bahia, V. R. L., Nakaghi, L. S. O., De Stefani, M. V., Gonçalves, A. M., \& Junior, J. M. P. (2016). Ontogeny of the Digestive Enzymes of Tadpoles of Lithobates catesbeianus. Copeia, 104(4), 838-842. [CrossRef]

Seixas Filho, J. T., Mello, S. C. R. P., Silva, J. M. F., Tomas, J. E., \& Melo, C. M. S. (1998). Efeito dos níveis de energia e proteína bruta no desempenho de girinos (Rana catesbeiana Shaw, 1802). Revista Brasileira de Zootecnia, 27(4), 664-669. http://www.sbz.org.br/revista/ artigos/1840.pdf

Seixas Filho, J. T., Oliveira, M. G. A., Donzele, J. L., Gomide, A. T., \& Menin, E. (2000). Atividade de lipase em quimo de três espécies tropicais de peixes Teleostei de água doce Lipase activity in the chime of three Teleostei freshwater fish. Revista Brasileira de Zootecnia, 29(1), 6-14. [CrossRef]

Seixas Filho, J. T. D., Oliveira, M. G. A., Moura, G. D. S., Lanna, E. A. T., Garcia, S. L. R., \& Lima, J. L. P. (2010). Influence of supplying bullfrog tadpoles with feed containing $28 \%$ crude protein on performance and enzymatic activities. Revista Brasileira de Zootecnia, 39(1), 9-17. [CrossRef]

Toloza, E. M., \& Diamond, J. M. (1990). Ontogenetic development of nutrient transporters in bullfrog intestine. American Journal of Physiology-Gastrointestinal and Liver Physiology, 258(5), 760-769. [CrossRef]

Thibaudeau, D. G., \& Altig, R. (1988). Sequence of ontogenetic development and atrophy of the oral apparatus of six anuran tadpoles. Journal of Morphology, 197(1), 63-69. [CrossRef]

Veiga, A., de Miranda, R. G. B., \& do Nascimento Santos, C. A. (1998). Efeito da granulometria da ração sobre o desempenho de girinos de Rana catesbeiana. R. Bras. Zootec., 27(2), 224-230. http://www.sbz. org.br/revista/artigos/1860.pdf

Walter, H. E. (1984). Proteases and their inhibitors. 2. 15. 2 Method with haemoglobin, casein and azocoll as substrate. Methods of enzymatic analysis, 30(5), 270-277. 